\title{
Improved development of rabbit one-cell embryos to the hatching blastocyst stage by culture in a defined, protein-free culture medium*
}

\author{
E. W. Carney† and R. H. Foote \\ Department of Animal Science, Cornell University, Ithaca, New York 14853-4801, USA
}

\begin{abstract}
Summary. In Exp. 1, Medium 199 and Medium RD (RPMI-1640 and Dulbecco's MEM, 1:1 v/v) were compared in a $2 \times 2$ factorial design by supplementing each with $15 \mathrm{mg}$ bovine serum albumin (BSA)/ml or $1 \mathrm{mg}$ polyvinyl alcohol (PVA)/ml. All media contained $5 \mu \mathrm{g}$ insulin $/ \mathrm{ml}, 5 \mu \mathrm{g}$ transferrin $/ \mathrm{ml}, 5 \mathrm{ng}$ selenium $/ \mathrm{ml}$ (ITS), and $10 \mathrm{ng}$ epidermal growth factor (EGF) $/ \mathrm{ml}$. One-cell embryos were cultured at $39^{\circ} \mathrm{C}$ with $5 \% \mathrm{CO}_{2}$ in air for $65 \mathrm{~h}$ and then stained with Hoechst 33342 to determine blastomere number. Embryos in Medium 199 developed poorly $(P<0.001)$ when PVA was used instead of BSA (30 vs 76 cells/embryo), but developed rapidly in Medium RD with PVA or BSA (118 and 121 cells). Similar results were obtained in Exp. 2 in BSA- and PVA-free medium. In Exp. 3, the development of 1-cell embryos after $65 \mathrm{~h}$ in unsupplemented (protein-free) Medium RD (68\% blastocysts, 117 cells) did not differ $(P>0.37)$ from that obtained using Medium RD with insulin, ITS or EGF alone. Culture in proteinfree Medium RD for $96 \mathrm{~h}$ resulted in $82 \%$ of the 1-cell embryos forming blastocysts and $40 \%$ hatching through the zona pellucida. In a preliminary test of viability, 1-cell embryos cultured in this medium for 48 or $65 \mathrm{~h}$ and transferred to synchronous recipients resulted in $5 / 18(28 \%)$ and $3 / 24(12 \%)$ Day-15 viable fetuses. Cell counts of approximately 120 per blastocyst after culturing 1-cell embryos for $65 \mathrm{~h}$ in Medium RD indicated that cell division was more rapid than that obtained with all other media tested previously in this laboratory. This is the first report of rabbit embryo development from the 1-cell to the hatching blastocyst stage in a defined protein-free culture medium.
\end{abstract}

Keywords: albumin; polyvinyl alcohol; insulin; epidermal growth factor; rabbit; embryo

\section{Introduction}

The ability to culture mammalian preimplantation embryos in defined media has been a goal of developmental biologists for many years. The advantages of defined media, which contain only highly purified ingredients, are numerous. First, to understand fully the requirements for embryo development it is essential to know the precise composition of the medium in which embryos are grown. Secondly, supplementation with undefined components, such as serum or serum proteins, is a source of undesirable experimental variation. Finally, the use of a defined medium eliminates the potential introduction of viruses and bacteria, and their metabolites, which are common contaminants of undefined components (Ham, 1981).

The undefined component most commonly found in mammalian embryo culture media is bovine serum albumin (BSA). Many have previously termed simple media containing BSA as

${ }^{*}$ Reprint requests to Robert H. Foote.

†Present address: Division of Molecular and Developmental Biology, Mount Sinai Hospital Research Institute, Toronto, Ontario, Canada M5G 1 X5. 
defined, but clearly this is not the case as commercial BSA preparations are usually contaminated with hormones, growth factors, fatty acids, vitamins, and other naturally occurring substances (Westphal, 1970; Peters, 1975). Different lots of BSA vary tremendously in their ability to support embryo development (Kane, 1983). Even highly purified albumin is problematic due to its great capacity for binding substances in the defined portion of the culture medium, making their free concentration unknown to the investigator (Ham, 1981).

Attempts to culture rabbit embryos in defined media have met with limited success. When Kane \& Foote (1970) omitted BSA from their BSM II (modified Ham's F10) medium, 1-cell embryos reached the morula stage, but did not form blastocysts. The same result was observed upon replacement of BSA with the synthetic macromolecule, polyvinyl alcohol (Kane, 1987). We have now examined in-vitro development of rabbit 1-cell embryos to the hatching blastocyst stage and birth of live young after culture in a defined culture medium free of exogenous protein.

\section{Materials and Methods}

Culture media. Evaluated in this study were Medium 199, used in earlier rabbit embryo culture experiments (Carney et al., 1990), and Medium RD, previously untested with rabbit embryos. Medium RD is a 1:1 (v/v) mixture of RPMI1640 and Dulbecco's Modified Eagle's Medium (high glucose modification) introduced for the culture of hybridoma cells (Goldsby, 1989), but chosen for evaluation in the present study based on its use for the co-culture of mouse embryos with oviduct epithelial cells (Priestley \& Black, 1988). The compositions of Medium 199 and Medium RD are compared in Table 1 . No serum was added to any medium used.

Water used to prepare the media was purified by reverse osmosis and subsequent passage through a MilliQ ${ }^{\circledR}$ filtration system (Millipore, Bedford, MA, USA). Stock media were prepared by rehydrating bicarbonate-free powdered media (Gibco, Grand Island, NY, USA) with culture grade water and were stored for up to 2 months in glass bottles at $4^{\circ} \mathrm{C}$. In all experiments, $2.85 \mu \mathrm{g}$ sodium bicarbonate $/ \mathrm{ml}$ and an antibiotic-antimycotic solution (Gibco) composed of $100 \mathrm{U}$ penicillin-G/ml, $100 \mu \mathrm{g}$ streptomycin sulphate $/ \mathrm{ml}$, and $0.25 \mu \mathrm{g}$ amphotericin-B/ml (final concentrations) were added to the media on the day of use. Additional components indicated below were also added fresh.

Experiment 1 was a $2 \times 2$ factorial comparing Media 199 and RD supplemented with either $15 \mathrm{mg}$ Fraction V BSA $/ \mathrm{ml}$ (Sigma Chemical Co., St. Louis, MO, USA) or $1 \mathrm{mg}$ polyvinyl alcohol/ml (PVA; Type II, cold water soluble, Sigma). In Exp. 2, Media 199 and RD were used with or without BSA. In both experiments the media were also supplemented with $5 \mu \mathrm{g}$ insulin $/ \mathrm{ml}, 5 \mu \mathrm{g}$ transferrin $/ \mathrm{ml}, 5 \mu \mathrm{g}$ selenium $/ \mathrm{ml}$, and $10 \mathrm{ng}$ epidermal growth factor $/ \mathrm{ml}$ (Collaborative Research, Bedford, MA, USA). The concentrations selected were based on previous studies with rabbit embryos (Carney et al., 1990).

Experiment 3 was designed to determine the importance of supplementing Medium RD with insulin, transferrin, selenium, and epidermal growth factor. Embryos were cultured in Medium RD, without BSA or PVA, but which contained, at the same concentrations used previously: (a) the complete supplement, (b) insulin, transferrin, and selenium only, (c) epidermal growth factor alone, (d) insulin alone, or (e) no supplement. In Exp. 4, embryos were cultured for $120 \mathrm{~h}$ in protein-free Medium RD to determine maximal development in vitro in this medium.

Embryo collection and culture. One-cell embryos were collected from superovulated Dutch-belted does (Kennelly \& Foote, 1965) $19 \mathrm{~h}$ after LH by flushing oviducts with phosphate-buffered saline (Gibco) containing $1 \mathrm{mg} \mathrm{PVA} / \mathrm{ml}$ to facilitate embryo handling (Bavister, 1981; Kane, 1987) and $5 \times$ antibiotic-antimycotic solution. Embryos were washed twice with $3 \mathrm{ml}$ flushing medium each time. Any abnormal embryos or ova, as judged by the presence of a granular cytoplasm, irregular shape, or excessively thick mucin layer, were discarded. Embryos from each superovulated donor were divided equally and randomly assigned to treatment groups. Groups of 2-10 embryos were cultured for $65 \mathrm{~h}$ in individual wells of 4-well dishes (NUNC, Kamstrup, Denmark) containing $0.5 \mathrm{ml}$ medium at $39^{\circ} \mathrm{C}$ in an humidified atmosphere of $5 \% \mathrm{CO}_{2}$ in air. As the present study was concerned primarily with oviducal-stage embryos, the 65 -h culture period was chosen to approximate the $62-70 \mathrm{~h}$ time period in which rabbit embryos normally reside in the oviduct (Hodgson \& Pauerstein, 1976).

Evaluation of embryo development. In Exps 1-3, embryos were examined briefly using an inverted-phase contrast microscope $(\times 200)$ to determine morphological stage of development at approximately 24,48 and $65 \mathrm{~h}$ of culture. After evaluation at $65 \mathrm{~h}$, the embryos were fixed in $1 \%$ formalin. The number of blastomeres per embryo was determined by staining them for 3 min with the DNA-specific fluorochrome, Hoechst 33342, using a 3 min pre-stain with $0.1 \%$ trypan blue to quench fluorescence of sperm heads embedded in the mucin coat (Pursel et al., 1985). Accurate counting of nuclei at $\times 500-800$ under epifluorescence illumination was facilitated by the use of an ocular grid.

In Exp. 4, embryos were evaluated at $24,48,65,72,96$ and 120 h of culture and the percentages of early (intrazonal diameter $<134 \mu \mathrm{m}$ ), expanding (diameter $>134 \mu \mathrm{m}$ ), and hatching (cell mass extruding through zona pellucida) blastocysts were recorded. 
Embryo transfer. As a preliminary test of the developmental competence of embryos cultured in protein-free Medium RD, 1 -cell embryos collected $19 \mathrm{~h}$ after LH were cultured for 48 or $65 \mathrm{~h}$ and then transferred to the oviducal ampullae of synchronized pseudopregnant recipient does (Exp. 5). Donor-recipient synchronization was achieved by injecting both with LH or GnRH at the same time (Carney \& Foote, 1990). In general, embryos cultured for $48 \mathrm{~h}$ were early morulae, and those cultured for $65 \mathrm{~h}$ were late morulae or early blastocysts. However, all embryos in a given well were transferred at the appropriate time to avoid any selection bias. A subset of embryos recovered from the same donors was immediately transferred to serve as embryo controls. Mid-ventral laparotomies were done on Day 15 of gestation to determine the number of viable fetuses. After laparotomy, the abdomen was resutured and the recipients were allowed to complete their pregnancies.

Chemical analysis of PVA. A sample of polyvinyl alcohol was analysed by atomic flame emission spectroscopy to determine levels of 23 elemental contaminants. This analysis was provided by the Department of Plant Science Spectroscopy Laboratory at Cornell University.

Statistical analysis. The experiments were randomized complete blocks, with the embryos from each donor representing one complete block. This was done to control for embryo donor effects, which often were significant $(P<0.05)$. Yield of usable embryos ranged from 10-57/donor, with 5-11 donors used in each experiment. Experiments were repeated on a minimum of 3 days. Any unfertilized ova detected retrospectively by nuclear staining were excluded from the analyses.

The arcsine/square root transformation (Zar, 1984) was applied to percentage data, while blastomere number data were transformed logarithmically. Two-way analysis of variance was performed, using the general linear models procedure of the Statistical Analysis System (SAS Institute, Cary, NC). The experimental error variance was used to test differences among means based on protected Fisher's least significant difference tests (Snedecor \& Cochran, 1980), and $P<0.05$ was considered statistically significant. However, when biologically important relationships approached the arbitrary statistical significance level of $P<0.05$, the actual $P$ value is given.

\section{Results}

\section{Experiment 1}

Embryos cultured in Medium 199 with PVA had significantly fewer blastomeres $(P<0.001)$ after $65 \mathrm{~h}$ in culture than did embryos grown in Medium 199 with BSA (Table 2). Also, fewer blastocysts were actually formed in Medium 199, with PVA, but the difference was not significant $(P=0.11)$. In contrast, when embryos were cultured in Medium RD there was no significant $(P>0.83)$ reduction in development in response to substitution of PVA for BSA. In fact, there was a significantly higher percentage of blastocysts formed $(P<0.005)$, and a trend towards higher blastomere numbers $(P=0 \cdot 10)$ for embryos grown in RD with PVA compared with embryos cultured in BSA-supplemented Medium 199.

\section{Experiment 2}

The results (Table 3 ) indicate that Medium RD alone (no PVA or BSA) was equivalent to Medium RD plus BSA and, along with the results shown in Table 4, suggest that PVA does not play an important role. Again, development in Medium 199 was adversely affected by omission of BSA to about the same extent that it was when BSA was replaced with PVA.

\section{Experiment 3}

Development in Medium RD supplemented with insulin, transferrin, selenium, and epidermal growth factor was not significantly $(P>0.37)$ different from that obtained using Medium RD with epidermal growth factor alone, insulin alone, the combination of insulin, transferrin and selenium, or completely unsupplemented, protein-free Medium RD (Table 4). A possible exception to this was a slightly higher $(P=0 \cdot 10)$ percentage of expanded blastocysts formed in the group supplemented with insulin alone. 
Table 1. Composition of Medium 199 and Medium RD*

\begin{tabular}{|c|c|c|}
\hline \multirow[b]{2}{*}{ Components } & \multicolumn{2}{|c|}{ Molarity } \\
\hline & Medium RD & Medium 199 \\
\hline $\mathrm{CaCl}_{2}$ & $0.9 \times 10^{-3}$ & $1.8 \times 10^{-3}$ \\
\hline $\mathrm{KCl}$ & $5.4 \times 10^{-3}$ & $5.4 \times 10^{-3}$ \\
\hline $\mathrm{MgSO}_{4}$ & $0.6 \times 10^{-3}$ & $0.8 \times 10^{-3}$ \\
\hline $\mathrm{NaCl}$ & $10.6 \times 10^{-2}$ & $11.6 \times 10^{-2}$ \\
\hline $\mathrm{NaH}_{2} \mathrm{PO}_{4} \cdot \mathrm{H}_{2} \mathrm{O}$ & $0.5 \times 10^{-3}$ & $1.0 \times 10^{-3}$ \\
\hline $\mathrm{Fe}\left(\mathrm{NO}_{3}\right)_{3} \cdot 9 \mathrm{H}_{2} \mathrm{O}$ & $1.0 \times 10^{-7}$ & $1.8 \times 10^{-6}$ \\
\hline $\mathrm{NaHCO}_{3}$ & $3.4 \times 10^{-2}$ & $2.6 \times 10^{-2}$ \\
\hline Glucose & $17.9 \times 10^{-3}$ & $5.5 \times 10^{-3}$ \\
\hline \multicolumn{3}{|l|}{ Amino acids } \\
\hline Arginine & $7.5 \times 10^{-4}$ & $3.1 \times 10^{-4}$ \\
\hline Aspartic acid & $8.0 \times 10^{-5}$ & $4.5 \times 10^{-4}$ \\
\hline Cystine & $2.0 \times 10^{-4}$ & $8.3 \times 10^{-5}$ \\
\hline Glutamic acid & $7.0 \times 10^{-5}$ & $9.1 \times 10^{-4}$ \\
\hline Glutamine & $3.0 \times 10^{-3}$ & $6.8 \times 10^{-4}$ \\
\hline Glycine & $2.6 \times 10^{-4}$ & $6.9 \times 10^{-4}$ \\
\hline Histidine & $1.5 \times 10^{-4}$ & $1.0 \times 10^{-4}$ \\
\hline Hydroxyproline & $8.0 \times 10^{-5}$ & $7.6 \times 10^{-5}$ \\
\hline Isoleucine & $5.9 \times 10^{-4}$ & $3.0 \times 10^{-4}$ \\
\hline Leucine & $5.9 \times 10^{-4}$ & $9.2 \times 10^{-4}$ \\
\hline Lysine & $5.1 \times 10^{-4}$ & $3.8 \times 10^{-4}$ \\
\hline Methionine & $1.5 \times 10^{-4}$ & $2.0 \times 10^{-4}$ \\
\hline Phenylalanine & $2.3 \times 10^{-4}$ & $2.8 \times 10^{-4}$ \\
\hline Proline & $9.0 \times 10^{-5}$ & $3.5 \times 10^{-4}$ \\
\hline Serine & $3.4 \times 10^{-4}$ & $4.8 \times 10^{-4}$ \\
\hline Threonine & $4.8 \times 10^{-4}$ & $5.0 \times 10^{-4}$ \\
\hline Tryptophan & $5.0 \times 10^{-5}$ & $9.0 \times 10^{-5}$ \\
\hline Tyrosine & $2.5 \times 10^{-4}$ & $2.2 \times 10^{-4}$ \\
\hline Valine & $4.9 \times 10^{-4}$ & $4.3 \times 10^{-4}$ \\
\hline \multicolumn{3}{|l|}{ Vitamins } \\
\hline Biotin & $4.0 \times 10^{-7}$ & $4.1 \times 10^{-8}$ \\
\hline Calcium pantothenate & $4.6 \times 10^{-6}$ & $2.2 \times 10^{-8}$ \\
\hline Choline Cl & $3.0 \times 10^{-5}$ & $3.6 \times 10^{-7}$ \\
\hline Folic acid & $5.0 \times 10^{-6}$ & $2.1 \times 10^{-8}$ \\
\hline Inositol & $1.2 \times 10^{-4}$ & $2.8 \times 10^{-7}$ \\
\hline PABA & $3.6 \times 10^{-6}$ & $3.6 \times 10^{-6}$ \\
\hline Pyridoxal $\mathrm{HCl}$ & $1.0 \times 10^{-5}$ & $1.2 \times 10^{-7}$ \\
\hline Pyridoxine $\mathrm{HCl}$ & $2.0 \times 10^{-6}$ & $1.2 \times 10^{-7}$ \\
\hline Riboflavin & $8.0 \times 10^{-7}$ & $2.7 \times 10^{-10}$ \\
\hline Thiamine & $7.0 \times 10^{-6}$ & $3.0 \times 10^{-8}$ \\
\hline
\end{tabular}

Continued opposite.

\section{Experiment 4}

In this experiment (Figs 1, 2), 82\% of 881 -cell embryos cultured in unsupplemented Medium $\mathrm{RD}$ had reached the blastocyst stage and $40 \%$ were hatching through the zona pellucida by $96 \mathrm{~h}$ in culture. Mean intrazonal embryo diameter at $96 \mathrm{~h}$ was $146 \mu \mathrm{m}$. By $120 \mathrm{~h}, 51 / 88(58 \%)$ had a degenerate appearance, although $92 \%$ of the remaining 37 embryos had started to expand and $65 \%$ were hatching through the zona pellucida.

\section{Experiment 5}

As a preliminary measure of post-culture development potential, 1-cell embryos were cultured for 48 or $65 \mathrm{~h}$ in RD medium and then transferred to synchronous pseudopregnant recipients. This resulted in 5/18 (28\%) and 3/24 (12\%) Day-15 viable fetuses, respectively. These percentages were significantly $(P<0.02)$ less than those of immediately transferred control 1 -cell embryos 
Table 1. (Continued)

\begin{tabular}{|c|c|c|}
\hline \multirow[b]{2}{*}{ Components } & \multicolumn{2}{|c|}{ Molarity } \\
\hline & Medium RD & Medium 199 \\
\hline $\begin{array}{l}\text { Other } \\
\text { Phenol red } \\
\text { Glutathione (reduced) } \\
\text { Sodium pyruvate } \\
\text { Asparagine } \\
\text { Nicotinamide } \\
\text { Vitamin } \mathrm{B} 12 \\
\mathrm{Ca}\left(\mathrm{NO}_{3}\right)_{2} \cdot 4 \mathrm{H}_{2} \mathrm{O} \\
\mathrm{NaHPO}_{4} \cdot 7 \mathrm{H}_{2} \mathrm{O} \\
\text { Adenine } \\
\text { ATP } \\
\text { Adenylic acid } \\
\text { Cholesterol } \\
\text { Deoxyribose } \\
\text { Guanine } \mathrm{HCl} \\
\text { Hypoxanthine } \\
\text { Ribose } \\
\text { Sodium acetate } \\
\text { Thymine } \\
\text { Tween } 80 \\
\text { Uracil } \\
\text { Xanthine } \\
\text { Alanine } \\
\text { Cysteine } \\
\text { Ascorbic acid } \\
\text { a-Tocopherol } \\
\text { Calciferol } \\
\text { Menadione } \\
\text { Niacin } \\
\text { Niacinamide } \\
\text { Vitamin A }\end{array}$ & $\begin{array}{l}2.0 \times 10^{-5} \\
1.6 \times 10^{-6} \\
5.0 \times 10^{-4} \\
1.9 \times 10^{-4} \\
2.0 \times 10^{-5} \\
1.8 \times 10^{-9} \\
2.0 \times 10^{-4} \\
2.8 \times 10^{-3}\end{array}$ & $\begin{array}{l}2.7 \times 10^{-5} \\
1.8 \times 10^{-6} \\
1.1 \times 10^{-7} \\
5.2 \times 10^{-7} \\
3.7 \times 10^{-6} \\
1.6 \times 10^{-6} \\
2.2 \times 10^{-6} \\
3.3 \times 10^{-6} \\
6.1 \times 10^{-4} \\
2.4 \times 10^{-6} \\
1.5 \times 10^{-5} \\
2.7 \times 10^{-6} \\
2.0 \times 10^{-6} \\
5.6 \times 10^{-4} \\
7.0 \times 10^{-7} \\
2.8 \times 10^{-7} \\
1.7 \times 10^{-8} \\
2.5 \times 10^{-7} \\
5.8 \times 10^{-8} \\
2.0 \times 10^{-7} \\
2.0 \times 10^{-7} \\
3.9 \times 10^{-7}\end{array}$ \\
\hline $\begin{array}{l}\mathrm{pH} \text { under } 5 \% \mathrm{CO}_{2} \text { in air } \\
\text { Osmolality }\left(\mathrm{mosmol} / \mathrm{kg} \mathrm{H}_{2} \mathrm{O}\right)\end{array}$ & $308^{7 \cdot 45}$ & $327^{7 \cdot 53}$ \\
\hline
\end{tabular}

*Molarity values calculated from $\mathrm{g} / \mathrm{l}$ data in Gibco catalogue.

Table 2. Development of rabbit 1-cell embryos after culture for $65 \mathrm{~h}$ in serumfree Medium 199 or Medium RD supplemented with $1.5 \%$ BSA or $0.1 \%$ PVA*

\begin{tabular}{lcccc}
\hline & & \multicolumn{3}{c}{ Mean \pm s.e.m } \\
\cline { 3 - 5 } $\begin{array}{l}\text { Culture } \\
\text { medium }\end{array}$ & $\begin{array}{c}\text { No. of } \\
\text { embryos }\end{array}$ & $\begin{array}{c}\text { Blastocysts } \\
(\%) \dagger\end{array}$ & $\begin{array}{c}\text { Expanding } \\
\text { blastocysts }(\%) \dagger\end{array}$ & $\begin{array}{l}\text { Cell } \\
\text { no. }\end{array}$ \\
\hline M199 + BSA & 35 & $24 \pm 11 \cdot 4^{\mathrm{a}}$ & $0 \pm 0 \cdot 0^{\mathrm{a}}$ & $76 \pm 12 \cdot 7^{\mathrm{a}}$ \\
M199 + PVA & 35 & $2 \pm 2 \cdot 2^{\mathrm{a}}$ & $0 \pm 0 \cdot 0^{\mathrm{a}}$ & $30 \pm 9 \cdot 5^{\mathrm{b}}$ \\
RD + BSA & 36 & $63 \pm 10^{\mathrm{b}}$ & $4 \pm 3 \cdot 9^{\mathrm{a}}$ & $121 \pm 17^{\mathrm{b}}$ \\
RD + PVA & 27 & $72 \pm 11 \cdot 3^{\mathrm{b}}$ & $20 \pm 4 \cdot 4^{\mathrm{b}}$ & $118 \pm 13 \cdot 5^{\mathrm{ac}}$ \\
\hline
\end{tabular}

*All media also contained $5 \mu \mathrm{g}$ insulin $/ \mathrm{ml}, 5 \mu \mathrm{g}$ transferrin $/ \mathrm{ml}, 5 \mathrm{ng}$ selenium $/ \mathrm{ml}$, and $10 \mathrm{ng}$ epidermal growth factor $/ \mathrm{ml}$.

†The percentage of total embryos reaching the appropriate stage was determined for each culture well. Values shown are the means of those percentages \pm s.e.m.

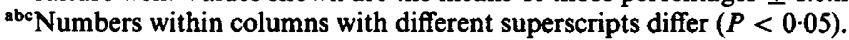


Table 3. Development of rabbit 1-cell embryos after culture for $65 \mathrm{~h}$ in serumfree Medium 199 or Medium RD, with or without $1.5 \% \mathrm{BSA}^{*}$

\begin{tabular}{lcccc}
\hline & & \multicolumn{3}{c}{ Mean \pm s.e.m } \\
\cline { 3 - 5 } $\begin{array}{l}\text { Culture } \\
\text { medium }\end{array}$ & $\begin{array}{c}\text { No. of } \\
\text { embryos }\end{array}$ & $\begin{array}{c}\text { Blastocysts } \\
(\%))^{\dagger}\end{array}$ & $\begin{array}{c}\text { Expanding } \\
\text { blastocysts }(\%) \dagger\end{array}$ & $\begin{array}{c}\text { Cell } \\
\text { no. }\end{array}$ \\
\hline M199+ BSA & 42 & $26 \pm 12 \cdot 3^{\mathrm{ab}}$ & $7 \pm 4 \cdot 3^{\mathrm{a}}$ & $85 \pm 20 \cdot 9^{\mathrm{a}}$ \\
M199 & 41 & $0 \pm 0 \cdot 0^{\mathrm{b}}$ & $0 \pm 0 \cdot 0^{\mathrm{a}}$ & $34 \pm 13 \cdot 8^{\mathrm{b}}$ \\
RD + BSA & 42 & $47 \pm 14 \cdot 8^{\mathrm{a}}$ & $19 \pm 9 \cdot 8^{\mathrm{a}}$ & $129 \pm 16 \cdot 4^{\mathrm{a}}$ \\
RD & 39 & $27 \pm 10 \cdot 9^{\mathrm{ab}}$ & $4 \pm 3 \cdot 8^{\mathrm{a}}$ & $119 \pm 12 \cdot 9^{\mathrm{a}}$ \\
\hline
\end{tabular}

*All media also contained $5 \mu \mathrm{g}$ insulin $/ \mathrm{ml}, 5 \mu \mathrm{g}$ transferrin $/ \mathrm{ml}, 5 \mathrm{ng}$ selenium $/ \mathrm{ml}$, and $10 \mathrm{ng}$ epidermal growth factor $/ \mathrm{ml}$, but no PVA was used.

†See Table 2, footnote 2.

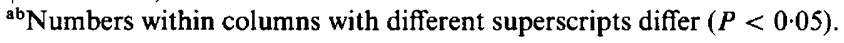

Table 4. Development of rabbit 1-cell embryos after culture for $65 \mathrm{~h}$ in Medium RD with or without insulin, transferrin, selenium, and/or epidermal growth factor

\begin{tabular}{|c|c|c|c|c|}
\hline \multirow[b]{2}{*}{$\begin{array}{l}\text { Culture } \\
\text { medium }\end{array}$} & \multirow[b]{2}{*}{$\begin{array}{l}\text { No. of } \\
\text { embryos }\end{array}$} & \multicolumn{3}{|c|}{ Mean \pm s.e.m } \\
\hline & & $\begin{array}{l}\text { Blastocysts } \\
(\%)^{*}\end{array}$ & $\begin{array}{c}\text { Expanding } \\
\text { blastocysts }(\%)^{*}\end{array}$ & $\begin{array}{l}\text { Cell } \\
\text { no. }\end{array}$ \\
\hline \multicolumn{5}{|l|}{ Medium RD plus: } \\
\hline+ ITS/EGF† & 64 & $59 \pm 10 \cdot 3$ & $16 \pm 7.7$ & $\begin{array}{l}121 \pm 10 \cdot 5 \\
122+12 \cdot 8\end{array}$ \\
\hline+ ITS $\dagger$ & 63 & $61 \pm 12 \cdot 3$ & $16 \pm 7 \cdot 4$ & $122 \pm 12 \cdot 8$ \\
\hline$+\mathrm{EGF} \dagger$ & 65 & $65 \pm 11 \cdot 4$ & $19 \pm 8 \cdot 4$ & $109 \pm 12 \cdot 8$ \\
\hline+ Insulin $\dagger$ & 63 & $64 \pm 12 \cdot 5$ & $28 \pm 9.8$ & $116 \pm 15 \cdot 4$ \\
\hline Medium RD only & 62 & $68 \pm 11 \cdot 8$ & $18 \pm 7 \cdot 1$ & $117 \pm 12 \cdot 1$ \\
\hline
\end{tabular}

*See Table 2, footnote 2 .

$\dagger 5 \mu \mathrm{g}$ insulin/ml, $5 \mu \mathrm{g}$ transferrin/ml, $5 \mathrm{ng}$ selenium/ml, and/or $10 \mathrm{ng}$ epidermal growth factor $/ \mathrm{ml}$. BSA or PVA were not used.

No significant differences $(P>0.05)$.

$(19 / 24,79 \%)$. In the 0,48 , and $65 \mathrm{~h}$ culture groups, 12,4 and 3 live young were delivered at term, respectively.

\section{Chemical analysis of PVA}

Although PVA did not appear to affect rabbit embryo development in vitro, its widespread use by embryologists, combined with a lack of information on PVA in the literature, were incentives for the collection of data describing chemical characteristics and impurities of PVA (Table 5), which is characterized by a wide range of molecular weights. Individual batches may differ substantially. The PVA contained an elevated amount of sodium, mainly due to the use of the dehydrating agent sodium oxide during manufacture. Analysis for 22 additional elements revealed quantities of elemental impurities similar to those of most reagent-grade chemicals.

\section{Discussion}

The results of this study demonstrate that rabbit 1-cell embryos can form blastocysts at a rate similar to the in-vivo rate, hatch through the zona pellucida, and retain the capacity to develop into 


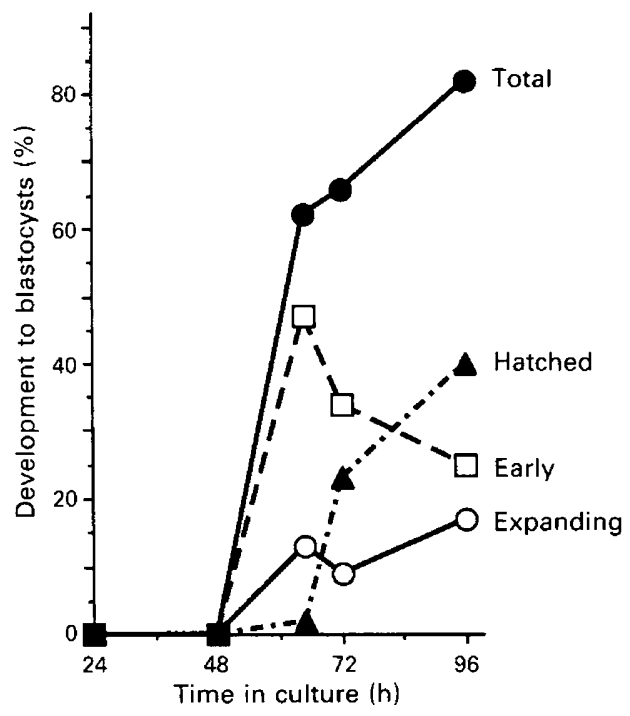

Fig. 1. Development to the blastocyst stage of one set $(n=88)$ of rabbit 1-cell embryos cultured in protein-free Medium RD. Data for the 120 -h time point are not shown (see text).

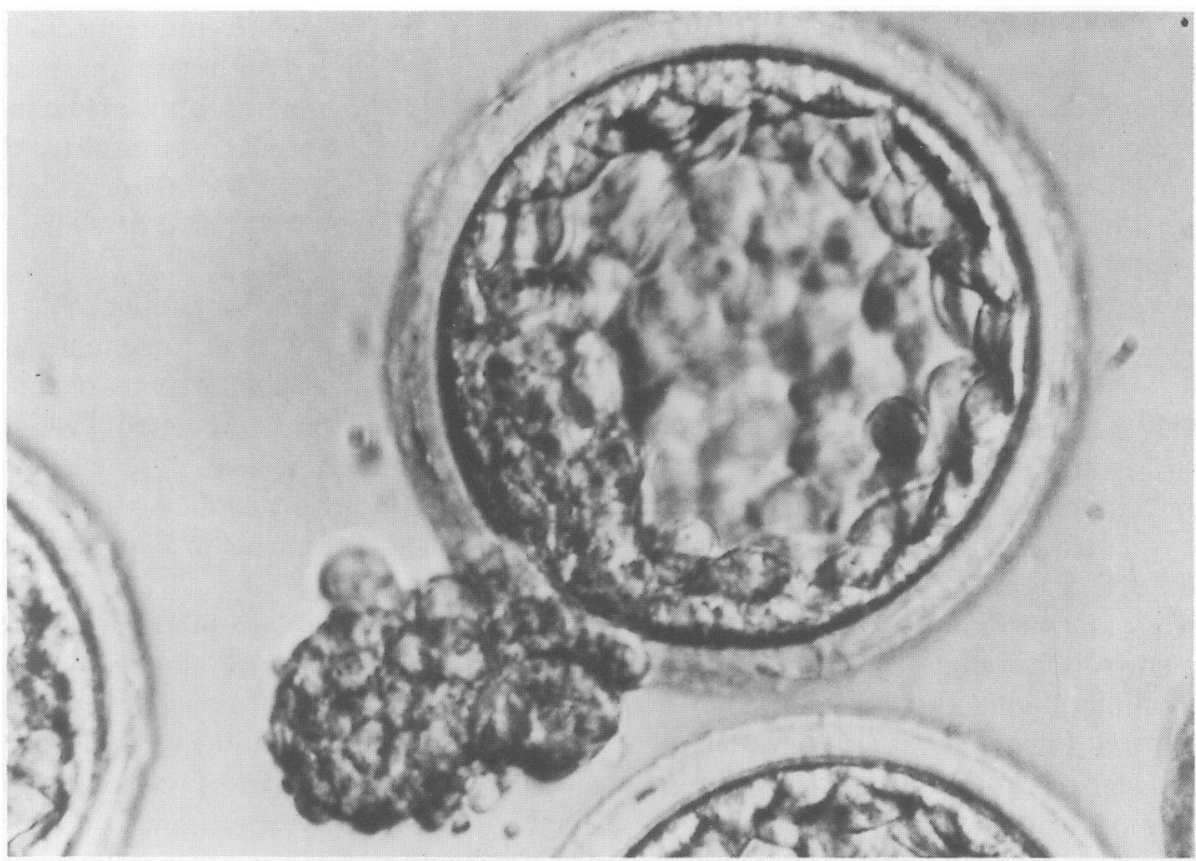

Fig. 2. Hatched (herniated) rabbit blastocyst obtained after culture from the 1-cell stage in protein-free Medium RD for $65 \mathrm{~h}(\times 100)$.

live young during culture in a defined protein-free medium called Medium RD. The only other species in which hatching has been obtained after culture from the 1-cell stage in the absence of exogenous protein has been the mouse (Ogawa \& Marrs, 1987). 
Table 5. Chemical characteristics* and atomic flame emission spectroscopic analysis of PVA

\begin{tabular}{ll}
\hline Chemical structure & $--\mathrm{CH}_{2}-\mathrm{CH}-\mathrm{CH}_{2}-\mathrm{CH}---$ \\
& $10000-30 \mathrm{OH}$ \\
Molecular weight & Hydrolysis of polyvinyl acetate \\
Synthesis & $98 \cdot 22 \%$ \\
Viscosity & $6 \cdot 2$ \\
pH of $4 \%$ solution & No analysis available \\
Impurities & Incapable of existence \\
$\quad$ Low, high molecular weight polymers & $2 \cdot 68 \%$ \\
$\quad$ Monomer & $<0 \cdot 38 \%$ \\
$\quad$ Volatiles & $<0 \cdot 0010 \%$ \\
Atomic flame emission spectroscopy analysis: & $<0 \cdot 0001 \%$ \\
$\mathrm{Na}$ (mainly as $\mathrm{Na}_{2} \mathrm{O}$ ) & $<0 \cdot 045 \%$ \\
$\mathrm{Ca}$ & $<4$ p.p.m. \\
$\mathrm{K}$ & $<1$ p.p.m. \\
$\mathrm{Yttrium}$ & Undetectable \\
$\mathrm{Si} \mathrm{Se}$ & $\mathrm{Cu}, \mathrm{B}, \mathrm{Zn}, \mathrm{Mo}, \mathrm{Al}, \mathrm{Co}, \mathrm{Cd}, \mathrm{Cr}, \mathrm{Ni}, \mathrm{Pb}, \mathrm{V}, \mathrm{As}$ \\
$\mathrm{P}, \mathrm{Mg}, \mathrm{Mn}, \mathrm{Fe}, \mathrm{S}$ & \\
\hline
\end{tabular}

*All data except elemental analysis provided by Sigma Chemical Co.

The initial plan leading to the present results was to replace BSA, the only undefined component in the media evaluated, with the synthetic macromolecule, PVA. Polyvinyl alcohol and similar polymers have been used by embryologists to prevent embryos from sticking to glass and plastic surfaces during in-vitro manipulation (Kane, 1987) and have been added to culture media to serve as a biologically inert macromolecule. The concentration of PVA chosen for use was one based on a prior report (Bavister, 1981), as well as previous experience. Other proteins in the media included highly purified insulin, transferrin, and epidermal growth factor. The results demonstrated that the requirement for macromolecules, such as BSA, by rabbit embryos for blastocyst development in Medium 199 and other culture media (Kane \& Foote, 1970; Kane, 1987) could be eliminated by culture in Medium RD without BSA (Table 2).

Having obtained positive results using Medium RD without BSA, but containing PVA, insulin, transferrin, selenium and epidermal growth factor, the next step was to omit these molecules systematically. In Exp. 2 (Table 3), absence of PVA appeared to be of no consequence, as the results were similar to those of the preceding experiment. Embryos in Medium 199 required BSA, whereas those in Medium RD developed at a similar rate with or without BSA. Lack of an effect of PVA supplementation on rate of development was also corroborated indirectly by the high percentage of blastocysts formed and high blastomere numbers achieved in all treatments in Exp. 3, when PVA was not used (Table 4).

It was of particular interest to know whether the presence of insulin, transferrin, selenium, and epidermal growth factor, as used in Exps 1 and 2, was critical for embryo development in Medium RD. Insulin and epidermal growth factor can stimulate development of mouse embryos in vitro (Caro et al., 1987; Harvey \& Kaye, 1988; Wood \& Kaye, 1989), but their effects on rabbit embryos were unknown. Surprisingly, development of embryos in Medium RD containing insulin, transferrin, selenium and/or epidermal growth factor, as judged by appearance and total cell counts, was no better than development of embryos in unsupplemented, protein-free Medium RD (Table 4).

That these factors did not increase rate of development does not preclude a role for them. The concentrations used in this experiment may not have been optimal for culture in Medium RD, or their effects could be manifested later in development, as in the case of insulin stimulation of mouse embryos (Gardner \& Kaye, 1986). Alternatively, rabbit embryos may contain endogenous growth and differentiation factors acting in an autocrine manner (Werb et al., 1989). 
Because the present study was concerned primarily with the culture requirements of oviducalstage embryos, embryos in Exps 1-3 were fixed after $65 \mathrm{~h}$ of culture to approximate the $62-70 \mathrm{~h}$ oviducal transit time in rabbits (Hodgson \& Pauerstein, 1976). The lower percentage of blastocysts formed from embryos cultured in Medium 199 reflects their slower rate of development, rather than their inability to form blastocysts. When allowed $96 \mathrm{~h}$ in culture, more than $80 \%$ of embryos in Medium 199 + BSA (E. W. Carney \& R. H. Foote, unpublished) or Medium RD (Fig. 1) form blastocysts.

Embryo transfer data demonstrated that embryos cultured in protein-free medium were capable of full-term development. However, the percentage of viable embryos was significantly lower than that of immediately transferred embryos. A possible confounding factor of embryo transfer studies in the rabbit is the presence of a mucin coat which is secreted by the oviducal epithelium and acquired by rabbit embryos during development in vivo (Greenwald, 1962). The lack of this mucin layer on cultured rabbit embryos (Fig. 2) has been suggested to be responsible for the historically poor survival rate of cultured and transferred rabbit embryos (Binkerd $\&$ Anderson, 1979).

Apart from allowing embryo development under highly defined conditions, the present results with Medium RD also constitute progress toward achieving development in vitro which temporally parallels development in vivo. Other media used previously (Carney et al., 1990) which supported slower rates of development than that obtained with Medium RD, include Basal Synthetic Medium II (Kane \& Foote, 1970), Ham's F10, Medium 199, and CZB (Chatot et al., 1989). Culture in Medium RD also yielded results superior to those achieved using a co-culture system with rabbit oviduct epithelial cells (Carney et al., 1990). The rate of cell division is still somewhat slower in vitro ( 120 cells) than in vivo (195 cells; Carney \& Foote, 1990), but the percentage of embryos forming blastocysts in Medium RD (68\%) was equal to that of embryos of the same age which had developed in vivo (Carney \& Foote, 1990).

Two questions arising from these experiments are: (l) what is the function of BSA in suboptimal media, such as Medium 199, and (2) how is this function replaced or made obsolete by culture in Medium RD? One possible explanation relates to the high-capacity, low-specificity binding properties of BSA (Peters, 1975). Medium 199 contains 15 additional compounds which are not in Medium RD (Table 1), some of which may be inhibitory. Fissore et al. (1990) found that BSA can be replaced by ethylenediaminetetraacetic acid (EDTA) for the culture of mouse zygotes into blastocysts. Therefore, the function of BSA in Medium 199, and possibly other suboptimal media, may be to protect embryos by binding inhibitory molecules.

A different hypothesis is based on the concentration of inositol, which is more than 400 times higher in Medium RD $(117 \mu \mathrm{M})$ than in Medium $199(0.28 \mu \mathrm{M})$. The inositol concentration in rabbit oviduct fluid has been reported to be $14 \mathrm{~mm}$ (Gregoire et al., 1962). Inositol may have a key role in the regulation of rabbit embryo growth, as increased blastocyst expansion (Kane, 1989) and incorporation of radiolabelled thymidine and amino acids were observed upon raising the concentration of inositol in a modified Ham's F10 medium from 3 to $75 \mu \mathrm{M}$ (Kane et al., 1988). In media which contain extremely low levels of inositol, BSA may benefit embryos by providing inositol in bound form.

The simplest explanation for the success of Medium RD may be that its balance of amino acids, vitamins, carbohydrates and salts are more nearly optimal for the culture of rabbit embryos than other media tested. Studies with somatic cell lines indicate that requirements for the addition of serum, growth factors, or conditioning by feeder cells to achieve maximal cell growth can be reduced drastically by optimizing the low molecular weight portion of culture media (McKeehan et al., 1981).

In conclusion, a protein-free medium has been found to promote more rapid embryo development in the rabbit than was obtained previously by co-culture with oviduct cells, or with other culture media tested (Carney et al., 1990). This result represents significant progress towards achieving the dual goals of improving embryo development in vitro and obtaining such development 
in a defined culture medium. The ability to obtain excellent development of rabbit embryos in defined media will facilitate a more precise understanding of the requirements for mammalian preimplantation embryo development, as investigators now can have strict control over culture medium composition, and variability between laboratories should be reduced.

This work was supported by NICHD National Cooperative Program on Non-Human In Vitro Fertilization and Preimplantation Development and was funded by the National Institute of Child Health and Human Development, NIH, through Cooperative Agreement HD21939. We thank M. Simkin, P. Farrell and E. Wilson for surgical and other technical assistance and Vetrepharm for providing the $\mathbf{L H}$.

\section{References}

Bavister, B.D. (1981) Substitution of a synthetic polymer for protein in a mammalian gamete culture system. $J$. exp. Zool. 217, 45-51.

Binkerd, P.E. \& Anderson, G.B. (1979) Transfer of cultured rabbit embryos. Gamete Res. 2, 65-73.

Carney, E.W. \& Foote, R.H. (1990) Effects of superovulation, embryo recovery, culture system and embryo transfer on development of rabbit embryos in vivo and in vitro. J. Reprod. Fert. 89, 543-551.

Carney, E. W., Tobback, C. \& Foote, R.H. (1990) Coculture of rabbit I-cell embryos with rabbit oviduct epithelial cells. $J$, in Vitro Cell. Devl. Biol. 26, 629-635.

Caro, C.M., Trounson, A. \& Kirby, C. (1987) Effect of growth factors in culture medium on the rate of mouse embryo development and viability in vitro. $J$. in Vitro Fert. Embryo Transfer 4, 265-268.

Chatot, C.L., Ziomek, C.A., Bavister, B.D., Lewis, J.L. \& Torres, I. (1989) An improved culture medium supports development of random-bred 1-cell mouse embryos in vitro. J. Reprod. Fert. 86, 679-688.

Fissore, R.A., Jackson, K.V. \& Kiessling, A.A. (1990) Mouse zygote development in culture medium without protein in the presence of ethylenediaminetetraacetic acid. Biol. Reprod. 41, 835-841.

Gardner, H. \& Kaye, P.L. (1986) The effect of insulin treatment during preimplantation culture on foetal development in the mouse. Proc. Aust. Soc. Reprod. Biol. 18, P3, Abstr.

Goldsby, R. (1989) A practical guide to making hybridomas. In Nucleic Acid and Monoclonal Antibody Probes, pp. 367-382. Eds B. Swaminathan \& G. Prakash. Marcel Dekker, New York,

Gregoire, A.T., Gongsakdi, D. \& Rakoff, A.E. (1962) The presence of inositol in reproductive tract secretions of the female rabbit. Fert. Steril. 13, 432-435.

Greenwald, G.S. (1962) The role of the mucin layer in development of the rabbit blastocyst. Anat. Rec. 142, 407-415.

Ham, R.G. (1981) Introduction: cell growth requirements - the challenge we face. In The Growth Requirements of Vertebrate Cells in Vitro, pp. 1-15. Eds C. Waymouth, R. G. Ham \& P. J. Chapple. Cambridge University Press, Cambridge.

Harvey, M.B. \& Kaye, P.L. (1988) Insulin stimulates protein synthesis in compacted mouse embryos. Endocrinology 122, 1182-1184.

Hodgson, B.J. \& Pauerstein, C.J. (1976) Comparison of oviductal transport of fertilized and unfertilized ova after HCG or coitus-induced ovulation in rabbits. Biol. Reprod. 14, 377-380.

Kane, M.T. (1983) Variability in different lots of commercial bovine serum albumin affects cell multiplication and hatching of rabbit blastocysts in culture. J. Reprod. Fert. 69, 555-558.

Kane, M.T. (1987) Minimal nutrient requirements for culture of one-cell rabbit embryos. Biol. Reprod. 37, $775-778$.

Kane, M.T. (1989) Effects of the putative phospholipid precursors, inositol, choline, serine and ethanolamine, on formation and expansion of rabbit blastocysts in vitro. J. Reprod. Fert. 87, 275-279.

Kane, M.T. \& Foote, R.H. (1970) Culture of two- and four-cell rabbit embryos to the expanding blastocyst stage in synthetic media. Proc. Soc. exp. Biol. Med. 133, 921-925.

Kane, M.T., Bavister, B.D. \& Fahy, M. (1988) Watersoluble vitamins stimulate in vitro development of rabbit and hamster blastocysts. Proc. 11th Int. Cong. Anim. Reprod. \& A.I., Dublin, 11, 473, Abstr.

Kennelly, J.J. \& Foote, R.H. (1965) Superovulatory response to pre- and post-pubertal rabbits to commercially available gonadotrophins. J. Reprod. Fert. 9, 177-188.

McKeehan, W.L., McKeehan, K.A. \& Ham, R.G. (1981) The relationship between defined low-molecularweight substances and undefined serum-derived factors in the multiplication of untransformed fibroblasts. In The Growth Requirements of Vertebrate Cells in Vitro, pp. 223-243. Eds C. Waymouth, R. G. Ham \& P. J. Chapple. Cambridge University Press, Cambridge.

Ogawa, T. \& Marrs, R.P. (1987) The effect of protein supplementation on single-cell mouse embryos in vitro. Fert. Steril. 47, 156-161.

Peters, T. (1975) Serum albumin. In The Plasma Proteins, Vol. 1, pp. 133-181. Ed. C. F. Putman. Academic Press, New York.

Priestley, J.B. \& Black, D.L. (1988) Co-culture of preimplantation mouse embryos with oviduct epithelial cells. Biol. Reprod. 38 (Suppl. 1), 12, Abstr.

Pursel, V.G., Wall, R.J., Rexroad, C.E., Jr, Hammer, R.E. \& Brinster, R.L. (1985) A rapid wholemount staining procedure for nuclei of mammalian embryos. Theriogenology 24, 687-700.

Snedecor, G.W. \& Cochran, W.G. (1980) Statistical Methods. Iowa State University Press, Ames. 
Werb, Z., Schultz, G.A., Pedersen, R.A., Sturm, K. \& Rappolee, D.A. (1989) Growth factor and growth factor receptor gene expression in peri-implantation mouse embryos. J. Cell Biochem., Suppl. 13B, CC009, Abstr.

Westphal, W. (1970) Corticosteroid-binding globulin and other steroid hormone carriers in the blood stream. J. Reprod. Fert., Suppl. 10, 15-38.
Wood, S.A. \& Kaye, P.L. (1989) Effects of epidermal growth factor on preimplantation mouse embryos. $J$. Reprod. Fert. 85, 575-582.

Zar, J.J. (1984) Biostatistical Analysis. Prentice-Hall, Englewood Cliffs.

Received 26 March 1990 